\title{
sciendo
}

\section{Pitfalls of DSGE Model APPROACH in Monetary UNion}

\section{Zlatica Konôpková ${ }^{1}$}

\begin{abstract}
This paper investigates the impact of country size on the DSEG model estimation of the monetary union. Following DSGE model for fiscal policy simulations (FiMod) the union is considered to have a two-country structure, the investigated country has weight in union equal to its population share and the second country represents the rest of members. The model is estimated for different country sizes and it is found there are two areas of equilibrium instability which covers 11 of 19 European Monetary Union members. The result is in contrary with Stähler and Thomas (2012) who estimated FiMod for Spain and stated that model can be recalibrated to every member of the monetary union. According to the result the size of country matters and affects the stability of equilibrium. Therefore, special attention is paid to small economies in monetary union. The results and consequences are then discussed with examples from recent history.
\end{abstract}

\section{Keywords}

DSGE, Fiscal Policy, Small Economy, Union

\section{Introduction}

The monetary union has become one of the most doubted modern economic institution in recent years. After worldwide financial crisis in 2007-2008 and especially after following debt crisis in European Monetary Union, questions have emerged to challenge the real pros and cons of membership in union. Is the real benefit from union bigger than the costs? Is it possible to create stable union from heterogeneous countries? Are we able to control the whole union without coordinated fiscal policy? Have we learnt anything from the crisis? European Monetary Union (EMU, also called euro area or Eurozone) is a monetary union formed by 19 of the 28 European Union (EU) member states which have adopted common currency - the euro $(€)$. EMU consists of members heterogenous in size, population, but most importantly still heterogenous in economic power, level, growth and other economic indicators. In case of such heterogeneity, monetary union faces asymmetric shocks that challenge common monetary policy. This problem can be solved in two ways, either by

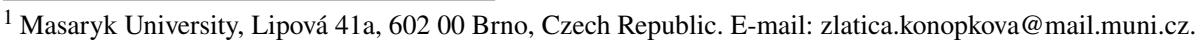


applying more convergence policies to reduce heterogeneity, or by introducing a common fiscal policy that will respond to shocks more effectively. The latter, however, requires political will that is not present in EMU nowadays. More about theory of monetary union and case of EMU analysis can be found in De Grauwe (2016).

Small economies in monetary unions are usually considered to be little players without any significant impact, but Eurozone is not typical union of countries with the same currency. First of all, its members were joint in politico-economic European Union to fulfil economic, social, cultural and political goals. Economic union with an internal single market for all members and system of funds to small economies in order to support sustainable long run economic growth creates suitable environment for possible fiscal effects between members regardless of the size of the economy (the transition is confirmed by several studies, see e.g. Beetsma and Giuliodori (2010), Faini et al. (2006), Caporale and Girardi (2013) or Belke and Osowski (2019)). Fiscal policy without coordination and restrictions therefore allows each country to make decisions with respect to its current and all possible future positions relying on the help of other members.

The aim of this work is to investigate the impact of country's size (in terms of population size) on the results of the DSGE model approach applied to the environment of monetary union. Next section of paper briefly presents the main features of DSGE modelling. Third section presents the most important components of DSGE model for fiscal policy simulations (FiMod) used for analysis. Finally, the fourth section presents the results presented. It is shown that the country size matters in analysis which is in contrary with Stähler and Thomas (2012) who estimated FiMod for Spain and stated that model can be recalibrated to every member of the monetary union. The consequences, especially for the position of small economy, are then discussed with examples from recent history.

\section{DSGE modelling}

Dynamic stochastic general equilibrium models (DSGE) are becoming more and more popular in recent years. The models are built on microeconomic theoretical background of optimizing agents divided into sectors covering whole economy. Government and central bank affect the economy through the rules for fiscal and monetary policy. Available information from data and economic experiments are introduced in order to fit model as much as possible on investigated economy.

The origin of DSGE approach can be dated into the years after the Lucas critique (1976) had been introduced. This approach was developed in order to be more immune to the critique. It is hard to identify the first DSGE model as the progress from neo-Keynesians modelling was slow and gradual, but it is worth to mention introductory and the most cited book of Galí (2008) on DSGE modelling. More on history can be found in e.g. Slanicay (2014).

Researchers and central banks develop their own version of DSGE model to explain various situations in economy and that predict reaction on future decision or unexpected shocks. The modelling is characterized by high rate of knowledge transfer where notably small economies takes over models prepared by big or developed countries. As an example, we can mention DSGE models of Slovakia. Zeman and Senaj (2009) introduced medium size 
DSGE model for Slovakia (developed based on Cuche-Curti et al. (2009) model for Swiss economy) to study four different shocks: monetary policy loosening, expansionary fiscal policy and shocks in productivity and in oil price. The model does not take into account the position of small economy in the monetary union.

After the crisis in 2008 there is also special attention paid to fiscal policy as it seems that monetary policy cannot be effective anymore. The mentioned DSGE model for Slovakia has a rather stylized representation of the fiscal side. Therefore, Múčka and Horváth (2015) introduce the DSGE model (using Pytlarczyk (2005) model for German economy) considering an array of fiscal instruments presented on the revenue and the expenditure side. The country is a member of monetary union of two-country structure.

We introduce the model of the monetary union following Stähler and Thomas (2012) and their DSGE model FiMod that is used for fiscal policy simulations and analyse its suitability for estimation of economies of different sizes in monetary union.

\section{FiMod}

The monetary union is considered to have a two-country structure of home and foreign economy. The population size of the whole union is normalized to unity where fraction $\omega \in(0,1)$ lives in the investigated home country and the rest population $(1-\omega)$ lives in big foreign country representing all other members of union. All relations and mechanisms are assumed to be the same in both regions, but they differ in structural parameters and steady state values. The model is fairly extensive, so only main and most important parts of model for home country are mentioned. The down indexes $\mathrm{A} / \mathrm{B}$ are used to mark the value corresponding to the home/foreign country.

\section{Households}

Households in each country are allowed to consume both home and foreign products. They are also the only supplier of labor in economy and have the discounted welfare function and utility function:

$$
\begin{gathered}
E_{o}\left\{\sum_{t=0}^{\infty} \beta^{t} u_{t}\left(c_{t}^{i}, c_{t-1}^{i}, \tilde{g}_{t}\right)\right\} \\
u_{t}\left(c_{t}^{i}, c_{t-1}^{i}, \tilde{g}_{t}\right)= \begin{cases}\frac{\left[c_{t}^{i}-h c_{t-1}^{i}\right]^{1-\sigma_{c}}-1}{1-\sigma_{c}}+\zeta \frac{\tilde{g}_{t}^{1-\sigma_{c}}-1}{1-\sigma_{c}}, & \sigma_{c}>0, \sigma_{c} \neq 1 \\
\log \left[c_{t}^{i}-h c_{t-1}^{i}\right]+\zeta \log \tilde{g}_{t}, & \sigma_{c}=1\end{cases}
\end{gathered}
$$

These functions are same for every type of household in economy marked by $i$. Variable $c_{t}^{i}$ is consumption of final goods and $\tilde{g}_{t}$ represents the government services given to households. The parameter $\sigma_{c}$ is the coefficient of relative risk aversion, $h$ is the degree of habit formation in consumption and finally $\zeta$ is the relative weight of services given by government. The distribution of home/foreign goods in consumption basket depends on 
size of home country $\omega$ and on the degree of home bias in consumption $\psi$ where $P_{A t}, P_{B t}$ are price indexes:

$$
\frac{c_{A t}^{i}}{c_{B t}^{i}}=\left(\frac{\omega+\psi}{1-\omega-\psi}\right) \frac{P_{B t}}{P_{A t}} .
$$

Following Galí (2008) only fraction $(1-\mu)$ of households can optimize their consumption without restriction on liquidity. Optimizing Ricardian households have access to capital markets and are able to substitute and distribute their consumption in time. Households spend their income on consumption, investments, buying bonds and paying taxes (from consumption, wages, investments, bonds and lump-sum taxes). Their income consists of profits from owning a firm, returns on capital investments, home and foreign bonds. They also receive various subsidies, wages from private and public sector and finally benefit in unemployment. Assuming the law of motion for capital with investments adjustment costs:

$$
k_{t}^{o}=\left(1-\delta^{k}\right) k_{t-1}^{o} 1+\left[1-\frac{\kappa_{I}}{2}\left(\frac{I_{t}^{o}}{I_{t-1}^{o}}\right)^{2}\right] I_{t}^{o},
$$

the budget constraint of Ricardian households is equal to:

$$
\begin{aligned}
& \left(1+\tau_{t}^{c}\right) c_{t}^{o}+I_{t}^{o}+\frac{B_{t}^{o}+D_{t}^{o}}{P_{t}}+\frac{T_{t}}{(1-\mu)}=\frac{\Pi_{t}}{P_{t}}+\left(\left(1+\tau_{t}^{k}\right) r_{t}^{k}+\tau_{t}^{k} \delta_{t}^{k}\right) k_{t-1}^{o}+ \\
& +\frac{R_{t-1} B_{t-1}^{o}}{P_{t}}+\frac{R_{t-1}^{e c b} e^{-\psi_{d}\left(d_{t-1}-d\right) / Y_{t-1}} D_{t-1}^{o}}{P_{t}}-\tau_{t}^{b} \frac{\left(R_{t-1}-1\right) B_{t-1}^{o}}{P_{t}}+\frac{S u b_{t}}{(1-\mu)}+ \\
& +\left(1-\tau_{t}^{w}\right)\left(w_{t}^{p} n_{t}^{p, o}+w_{t}^{g} n_{t}^{g, o}\right)+\left(1-n_{t}^{p, o}-n_{t}^{g, o}\right) \kappa^{B}
\end{aligned}
$$

Non-Ricardian households, remaining $\mu$ part, are not allowed to save or borrow money in time, therefore they can spend on consumption only their actual income from wages and unemployment benefit.

$$
\left(1+\tau_{t}^{c}\right) c_{t}^{r}=\left(1-\tau_{t}^{w}\right)\left(w_{t}^{p} n_{t}^{p, r}+w_{t}^{g} n_{t}^{g, o}\right)+\left(1-n_{t}^{p, r}-n_{t}^{g, r}\right) \kappa^{B}
$$

\section{Production}

Production process in economy is divided into three sectors of retail, intermediate goods and labor firms that produce homogenous labor. Retailers buy the intermediate goods and create the final products that is sold under perfect competition. The maximization problem of representative firm:

$$
\max _{\left\{\tilde{y}_{t}(j): j \in[0, \omega]\right\}} P_{A t}\left(\int_{0}^{\omega}\left(\frac{1}{\omega}\right)^{\frac{1}{\varepsilon}} \tilde{y}_{t}(j)^{\frac{\varepsilon-1}{\varepsilon}} d j\right)^{\frac{\varepsilon}{\varepsilon-1}}-\int_{0}^{\omega} P_{A t}(j) \tilde{y}_{t}(j) d j, \quad \varepsilon>1
$$


results in total demand for each intermediate input.

$$
\omega \tilde{y}_{t}(j)=y_{t}(j)=\left(\frac{P_{A t}(j)}{P_{A t}}\right)^{-\varepsilon} Y_{t} .
$$

The sector of intermediate goods is characterized by following technology depending on total factor productivity $\varepsilon^{a}$, public stock capital determined by government $k_{t-1}^{g}$, demand for capital services $\tilde{k}_{t}(j)$ and for labor services $l_{t}(j)$.

$$
y_{t}(j)=\varepsilon^{a}\left(k_{t-1}^{g}\right)^{\eta}\left(\tilde{k}_{t}(j)\right)^{\alpha}\left(l_{t}(j)\right)^{1-\alpha}
$$

According to Calvo pricing every period there is a randomly chosen fraction $\theta_{p}$ of firms that cannot re-optimize their prices, remaining part choose the price $\widetilde{P_{A t}}$ in order to maximize their profit. As a result, the law of motion of the price level is given by:

$$
P_{A t}=\left[\theta_{p}\left(P_{A t-1}\right)^{1-\varepsilon}+\left(1-\theta_{p}\right)\left(\widetilde{P_{A t}}\right)^{1-\varepsilon}\right]^{1 /(1-\varepsilon)}
$$

The labor market is the most complicated sector in production, the details are not presented here and can be found in original work of Stähler and Thomas (2012). The process of matching employers with employees is present in the sector and so that wage bargaining. Similar to previous optimizations, every period only fraction of firms is allowed to renegotiate the wages and the law of motion of for public $(g)$ or private $(p)$ sector is:

$$
N_{t}^{f}=\left(1-s^{f}\right) N_{t-1}^{f}+p^{f} \widetilde{U_{t}}, \quad f=p, g .
$$

Today's employment is given by employment that has survived from last period and plus the new matches from unemployed population.

\section{Fiscal and monetary policy}

Fiscal policy is performed by government and therefore its debt $b_{t}$ plays an important role. Debt accumulation can be expressed as:

$$
b_{t}=\frac{R_{t-1}}{\pi_{t}} b_{t-1}-P D_{t},
$$

where primary deficit $P D_{t}$ is defined as the difference of fiscal expenditures (government purchases, investments and employees, payments for unemployment benefits and subsidies) and revenues (social contributions, taxes from wages, bonds, consumption, investments and lump-sum taxes.

$$
\begin{aligned}
& P D_{t}=\left[\frac{C_{t}^{g}+I_{t}^{g}+\left[\left(1+\tau_{t}^{s c}\right) w_{t}^{g} N_{t}^{g}\right] p_{B t}^{1-\omega-\psi}}{p_{B t}^{1-\omega-\psi}}+\kappa^{B} U_{t}+S u b_{t}\right]- \\
& \left.\left[\left(\tau_{t}^{w}+\tau_{t}^{s c}\right)\left(w_{t}^{p} N_{t}^{p}+w_{t}^{g} N_{t}^{g}\right)+\tau_{t}^{b} \frac{R_{t-1}-1}{\pi_{t}} b_{t-1}+\tau_{t}^{C} C_{t}+\tau_{t}^{k}\left(r_{t}^{k}-\delta^{k}\right) k_{t-1}+T_{t}\right)\right]
\end{aligned}
$$


The government therefore has six instruments on the revenue side and five instruments on the expenditure side that can be used to affect the economy. Every group is characterized by rule.

Revenue side, for every instrument $X \in\left\{\tau^{w}, \tau^{s c}, \tau^{b}, \tau^{c}, \tau^{k}\right\}$ and its target $\bar{X}$ it holds:

$$
X_{t}=\bar{X}+\rho_{X}\left(X_{t-1}-\bar{X}\right)+\left(1+\rho_{X}\right) \Phi_{X} e_{x}^{a u x}\left(\frac{b_{t-1}}{Y_{t-1}^{t o t}} p_{B t}^{1-\omega-\psi}-\omega^{b}\right)+\varepsilon_{t}^{X}
$$

Expenditure side, for every instrument $X \in\left\{C^{g}, I^{g}, w^{g}, N^{g}, S u b, T\right\}$ and its target $\bar{X}$ it holds:

$$
\frac{X_{t}}{\bar{X}}=\left(\frac{X_{t-1}}{\bar{X}}\right)^{\rho_{x}}\left(\frac{b_{t-1}}{\omega^{b} Y_{t-1}^{t o t}} p_{B t}^{1-\omega-\psi}-\omega^{b}\right)^{\left(1-\rho_{x}\right) \Phi_{x}} \exp \left(\varepsilon_{t}^{X}\right),
$$

where an $\varepsilon_{t}^{X} \sim I I D$ is shock and $e_{x}^{a u x}$ is exogenous auxiliary variable for simulation purposes.

Monetary policy is controlled by one central bank for whole union with nominal interest rate $R_{t}^{e c b}$ and long-run targets on inflation and GDP growth. The responds are given by simple Taylor rule (exponent * marks the all other members of union).

$$
\frac{R_{t}^{e c b}}{\bar{R}^{e c b}}=\left(\frac{R_{t-1}^{e c b}}{\bar{R}^{e c b}}\right)^{\rho_{R}}\left\{\left[\left(\frac{\pi_{t}^{\tau^{c}}}{\bar{\pi}^{\tau^{c}}}\right)^{\omega}\left(\frac{\pi_{t}^{\tau^{c}, *}}{\bar{\pi}^{\tau^{c}, *}}\right)^{1-\omega}\right]^{\Phi_{\pi}}\left[\left(\frac{Y_{t}^{t o t}}{Y_{t-1}^{t o t}}\right)^{\omega}\left(\frac{Y_{t}^{t o t, *}}{Y_{t-1}^{t o t, *}}\right)^{1-\omega}\right]^{\Phi_{y}}\right\}^{\left(1-\rho_{R}\right)}
$$

\section{International linkages}

The final part of models are the international linkages between members of union which are given by trade of goods, services and international bonds. Net foreign asset position of home country changes according to:

$$
d_{t}=\frac{R_{t-1}^{e c b} e^{-\psi_{d}\left(d_{t-1}-d\right) / Y_{t-1}}}{\pi_{A t}} d_{t-1}+\frac{1-\omega}{\omega}\left(C_{A t}^{*}+I_{A t}^{*}\right)-p_{B t}\left(C_{B t}+I_{B t}\right),
$$

where the last difference of real exports and imports is trade balance $T B_{t}$. Zero net supply of international bonds holds:

$$
\omega d_{t}+(1-\omega) p_{B t} d_{t}^{*}=0
$$

\section{Calibration}

Before the model is estimated it is needed to introduce available information from data. Baseline parameters of the model are calibrated based on results stated in economic literature. The main purpose of our work is to analyse the changes in estimation for different sizes of country represented by parameter $\omega$, therefore all other baseline parameters 
are remained the same as in Stähler and Thomas (2012) and can be found in Table A in Appendix. Targeted steady state values can be estimated by Bayesian techniques or calculated as means of respective variables for some periods of time. For the matter of our analysis, exact values are not important as they do not affect the final stability of equilibrium and are assigned based on Stähler and Thomas (2012).

\section{Results and comments}

The population size of the whole union is normalized to unity, therefore for every country in monetary union it holds $\omega \in(0,1)$. The model was estimated for different values of parameter $\omega$ with change step 0.01 . Figure 1 displays the results of estimations. The domain interval is divided into three areas - two areas of instability on the edges of interval surrounding the stability area. The equilibrium is stable for values of $\omega$ in range from 0.03 to 0.44 .

Figure 1: Stability of equilibrium for all values of parameter $\omega$.

\begin{tabular}{|c|c|c|}
\hline Unstable & Stable & Unstable \\
\hline$\langle 0 ; 0.03\rangle$ & $(0.03 ; 0.44)$ & $\langle 0.44 ; 1\rangle$ \\
\hline
\end{tabular}

Source: Author's construction

This result is in contrary with Stähler and Thomas (2012) who estimated model for Spain and stated that model can be recalibrated to every member of the monetary union and used for estimation. According to our result the size of country matters and affects the stability of equilibrium. What does it mean for Eurozone and its members? Table 1 shows member countries and their share on Eurozone's population in 2018 sorted from the largest to the smallest. There is no country bigger than $25 \%$ of Eurozone population, 6 of 19 members fits into to the stability area, 2 members are on the edge between stable and unstable equilibrium and 11 are too small to result in stable equilibrium. It must be noted, that even more than half of the member countries are in the area of the instability, from the view of population together they represent only $10 \%$ of the whole Eurozone.

Let's focus in more details on situation of small economy in monetary union. Without further and detailed analysis of model structure one might conclude that there is no need to model small economy together with the monetary union. Small economy and its fiscal policy cannot have impact on the other members in union. We can model our economy as a single country without other external effects on union or in other words we do not have to assign the significant weight to the membership. Does this result reflect the reality? Are we truly allowed to neglect the other members while modelling the small economy in the monetary union? What if the small countries join and form a coalition against other members?

Recent history shows us a very good example why we should not neglect the relationships in monetary union. European debt crisis has started in 2009 when step by step several members (Greece, Portugal, Ireland, Spain and Cyprus) were unable to refinance their debt or to bail out over-indebted banks under their national supervision. As we can see in 
Table 1, Ireland and Cyprus are small economies in area of unstable equilibrium, Greece and Portugal are on the edge. The assistance of European Central Bank (ECB), other members (European Stability Mechanism - ESM) or International Monetary Fund (IMF) was required to help the countries. The origin of the crisis was in mismanagement of governments that might rely on stability of Eurozone and might not predict the real effects of their decisions. Another indirectly observable cause might be an inefficient system of funds that does not motivate government to improve their spending and create distortions on the market.

Table 1: Eurozone members and their values of parameter $\omega$.

\begin{tabular}{|l|c|l|c|}
\hline Country & $\mathbf{2 0 1 8}$ & Country & $\mathbf{2 0 1 8}$ \\
\hline Germany & 0,2427 & Slovakia & 0,0160 \\
France & 0,1962 & Ireland & 0,0142 \\
Italy & 0,1773 & Lithuania & 0,0082 \\
Spain & 0,1368 & Slovenia & 0,0061 \\
Netherlands & 0,0504 & Latvia & 0,0057 \\
Belgium & 0,0334 & Estonia & 0,0039 \\
Greece & 0,0315 & Cyprus & 0,0025 \\
Portugal & 0,0302 & Luxembourg & 0,0018 \\
Austria & 0,0259 & Malta & 0,0014 \\
Finland & 0,0162 & & \\
\hline
\end{tabular}

Source: Author's construction based on Eurostat (2019)

With some level of exaggeration, it can be stated that funds induce governments to spend more in their own interest at the expense of other members. Economic union without independent and strict fiscal control creates suitable environment for fiscal game with multiple players, as it has been already investigated by several studies, e.g. Kirsanova et al. (2018), Libich and Stehlík (2012) or Van Aarle et al. (2001). Members of union are in "Fiscal Wars" and can choose their dominant strategy relying on future help from other members of union and so that underestimate the consequences of their decisions. Almost all affected members by crisis are small economies. All the mentioned supports an idea of importance to control fiscal policy regardless the size of the country and an idea to jointly manage the decisions in fiscal union of countries that are already joint in monetary and economic union.

The most serious problems in Eurozone were in Greece. It has to be said that mismanagement of government was not the only problem, but the crisis was also deepened by revelations that government had misreported the data about levels of debt and deficit in the past. It has started the crisis of confidence in Greece's ability to meet its commitments and has led to increase of bond yields and to increase of cost for risk insurance on credit default swaps. The consequences of Greek depression have spread to all markets in Europe and small economy with only $3 \%$ percent of union's population influenced the whole monetary union. 
How could this happen? How is it possible that we did not predicted this situation in an age of super computers? There are few reasons hidden in limitation of conventional approach to economic policy and modelling.

\section{The failures of policy and modelling}

First of all, neither economic policy, nor models are able to reflect all processes and relations in economy. It is also not expected that they perfectly would, but the omission of important fact can result in incorrect conclusions. The FiMod model (and so that a lot of other models of the monetary union) omits the close fiscal relations of union's members that can spend at each other's expense and wage "Fiscal Wars" between each other. Those relations are very special in case the countries are already joint in any other union as it is a case of EMU and was discussed previously.

Another real problem is that both, economic policy and models, fail in estimation of current expectations of economic subjects and therefore they are not able to predict the true direction of reactions on politic decisions. The theoretical transmission mechanism of political decisions is in general considered valid and also confirmed by observations, but only if the real expectations of subjects are in line with theoretical framework. The expectations are mainly influenced by the level of credibility, that is hardly introduced to models. Once the institution lost the credibility in the eye of economic subjects, it is pretty hard to gain it back. In case of lack confidence in economy then any intervention need not to result in desired output. It is more common that it would end completely different as it was planned. Let's take a quick look on case of Eurozone and Greece.

Worldwide financial crisis exhausted the economies and they had started to face the problems with their public debts. The debts were cumulated from years of prosperity and mismanagement of government and were highly increased in years of crisis when the governments had tried to start up the economic growth. After revelations of Greece's fake statistics, the credibility of Greek government and European institutions was severely compromised. The public did not firstly believe in rescue plans and interventions made by ECB (lowering the interest rates, buying of Greek bonds, printing of money) has not started up the consumption and investment yet. In a result after few years there is still deflation risk, the consumption is quite low, and the interest rates have almost reached the zero-low bound.

It seems that traditional tools are out of date and it is needed to come with something unconventional, new and unexpected, but first work hard to gain the trust back. The governments have to be deliberate in decisions and consolidate the national budgets. In 2012, almost all members of EU ( 25 of 28) signed the Treaty on Stability, Coordination and Governance in the Economic and Monetary Union (Fiscal Stability Treaty) in order to reinforce the coordination of economic policies between the members and to forego the crisis caused by mismanagement of public finances. This treaty undermines the position and strength of countries in their "Fiscal Wars", but also reduces the state sovereignty. It was the concern of The Czech Republic and The United Kingdom and the main reason they refused to sign the Treaty. 
Secondly, the problem of modelling is how we formally categorize the size of economy and its position in union. The standard way is to use the simple ratio of population size, as it is used in FiMod model introduced in previous parts. Can population size measure the size of economy and its impact on union correctly? The answer is not so obvious. We can think about the shares of GDP (economic power) or GDP per capita (economic level), but the methods of calculations for these statistics are frequently criticized. They are also already affected by all economic variables especially debts of economies and therefore they are not completely exogenous and suitable.

Economy can have small population, relatively quite small economic power, but its economic level might be very high and therefore can affect the rest of union. Just consider as an example group of four members, e.g. Spain, Greece, Luxemburg and Slovakia. Luxemburg is the smallest country by population and by economic power, but it is the biggest country by economic level. Slovakia is the smallest by economic power, Spain is the biggest by population and economic power. Greece is the second biggest by population and economic power and the second smallest by economic level. It is hard to say which of these countries can affect the union the most and therefore it is hard to decide which of the presented measures is the most suitable.

Third problem is the way in which the models and their results are used and explained. The current models consist of dozens of equations, parameters, are difficult to be understood and their complexity requires more and more computing capacity (which is not a case anymore in age of computers). On the contrary, as much as possible theoretic generalization is introduced in order to quickly estimate the model and to retain the acceptable level of interpretability. Too complicated model is not a tool that would be preferred by politics to make decisions. The exceptions are considered to be negligible without significant impact on results. Following this trend, functional models are taken over with only small adjustments from country to country and it can easily result in incorrect conclusions.

\section{Conclusion}

In this paper we have investigated the influence of country size on the results of model estimation in the monetary union. We have introduced the main components of DSGE modelling, especially details of DSGE model FiMod developed for fiscal policy simulation. The model was estimated for different country sizes and it was found there are two areas of instability that affect the results. Out of 19 members, 6 fits into to the stability area, 2 are on the edge between stable and unstable equilibrium and 11 are too small to result in stable equilibrium. Therefore, special attention was paid to position of small economy in monetary union. The result could be lightly explained as there is no need to model it as a member of union because small economy cannot affect the union.

The arguments hidden in limitation of conventional approach to economic policy and modelling were introduced in order to refute this thoughtless conclusion. The omission of fiscal relations between members of monetary union, the wrong estimation of current expectations and the inability to introduce a level of credibility to model are indicated as main problems. Other issues to be considered are unclear terminology of "small economy" 
and current technical trend with dozens of equations and generalization without adequate emphasis on logical explanation in modelling.

All of these arguments should be carefully considered by policy makers in monetary union regardless of the size of the country, because in union with close relations every member counts. It might be interesting for future research to investigate the effect of coalition between small members in monetary union, the impact of the country size while using different model approaches (e.g. Vector autoregression) or combinations of approaches (e.g. with game theory).

\section{Acknowledgements}

This work was supported by funding of specific research at Faculty of Economics and Administration, project MUNI/A/1098/2018. This support is gratefully acknowledged.

\section{References}

Van Aarle, B., Engwerda, J., Plasmans, J. (2001). Monetary and Fiscal Policy Interaction in the EMU: A Dynamic Game Approach. Annals of Operations Research. 109(1), 221. Beetsma, R., Giuliodori, M. (2010). The Macroeconomic Costs and Benefits of the EMU and Other Monetary Unions: An Overview of Recent Research. Journal of Economic Literature, 48(3), 603-641.

Belke, A. H., Osowski, T. U. (2019), Measuring fiscal spillovers in EMU and beyond: A Global VAR approach. Scottish Journal of Political Economy, 66, 54-93.

Caporale, G. M., Girardi, A. (2013). Fiscal spillovers in the Euro area. Journal of International Money and Finance, 38 (2013), 84.e1-84.e16.

Cuche-Curti, N. A., Dellas, H., Natal, J.-M. (2009). DSGE-CH: A dynamic stochastic general equilibrium model for Switzerland. Swiss National Bank Working and Discussion Papers, vol. 5.

De Grauwe, P. (2016). Economics of Monetary Union. Oxford: Oxford University Press, edition 11.

Eurostat. (2019). Population on 1 January [tps00001]. Retrieved June 26, 2019, from https://ec.europa.eu/eurostat/tgm/table.do?tab=table\&init=1\&language=en \&pcode=tps0$0001 \&$ plugin $=1$.

Faini, R., Duranton, G., Hau, H. (2006). Fiscal Policy and Interest Rates in Europe. Economic Policy, 21(47), 443-489.

Galí, J. (2008). Monetary Policy, Inflation, and the Business Cycle: An Introduction to the New Keynesian Framework and Its Applications. Princeton: Princeton University Press.

Kirsanova, T., Machado, C., Ribeiro, A. P. (2018). Should the ECB Coordinate EMU Fiscal Policies? International Journal of Central Banking, 14(2), 237-280.

Libich, J., Stehlík, P. (2012). Monetary Policy Facing Fiscal Indiscipline under Generalized Timing of Actions. Journal of Institutional and Theoretical Economics (JITE), 168(3), 393-431.

Múčka, Z., Horváth, M. (2015). Fiscal Policy Matters - A New DSGE Model for Slovakia. Council of Budget Responsibility Discussion Paper 1/2015. 
Němec, D. (2013). Investigating Differences Between the Czech and Slovak Labour Market Using a Small DSGE Model with Search and Matching Frictions. Czech Economic Review, 7(1), 21-41.

OECD. (2019). The OECD tax-benefit data portal. Retrieved June 26, 2019, from http:// www.oecd.org/social/benefits-and-wages/data/

Pytlarczyk, E. (2005). An estimated DSGE model for the German economy within the euro area. Deutsche Bundesbank Discussion Paper Series 1: Economic Studies, 33.

Slanicay, M. (2014). Some Notes on Historical, Theoretical, and Empirical Background of DSGE Models. Review of Economic Perspectives, 14(2), 145-164.

Stähler, N., Thomas, C. (2012). FiMod - A DSGE model for fiscal policy simulations. Economic modelling, 29(2), 239-261.

Zeman, J., Senaj, M. (2009). DSGE model - Slovakia. National Bank of Slovakia Working Paper 3/2019, 4-37. 


\section{Appendix}

Table A: Baseline parameter calibration

\begin{tabular}{|c|c|c|}
\hline Target & Symbol & Home country \\
\hline \multicolumn{3}{|l|}{ Households } \\
\hline Share or Ricardian households & $1-\mu$ & 0.6 \\
\hline Discount factor & $\beta$ & 0.99 \\
\hline Risk aversion & $\sigma_{c}$ & 2 \\
\hline Habits in consumption & $h$ & 0.85 \\
\hline Home bias & $\psi ; \psi^{*}$ & $0.56 ; 0.03$ \\
\hline \multicolumn{3}{|l|}{ Production } \\
\hline Depreciation rate & $\delta$ & 0.025 \\
\hline Private capital share & $\alpha$ & 0.4 \\
\hline Public capital share & $\eta$ & 0.015 \\
\hline Adjustment cost parameter & $\kappa_{I}$ & 2.48 \\
\hline \multicolumn{3}{|l|}{ Labor market } \\
\hline Separation rate (private; public sector) & $s^{p} ; s^{g}$ & $0.06 ; 0.03$ \\
\hline Matching elasticity (private; public sector) & $\varphi^{p} ; \varphi^{g}$ & $0.5 ; 0.3$ \\
\hline Bargaining power & $\zeta$ & 0.5 \\
\hline \multicolumn{3}{|l|}{ Price and wage stickiness } \\
\hline Calvo parameter (prices) & $\theta_{p}$ & 0.75 \\
\hline Calvo parameter (existing wages) & $\theta_{w}$ & 0.8 \\
\hline Calvo parameter (new wages) & $\theta_{w}^{n}$ & 0.7 \\
\hline Market power (mark-up) & $\varepsilon$ & 6 \\
\hline \multicolumn{3}{|l|}{ Fiscal policy } \\
\hline Smoothing parameters & $\rho_{j}$ & $0-0.1$ \\
\hline Persistence parameters & $\rho_{j}$ & $0-0.85$ \\
\hline Stances & $\Phi_{j}$ & $0-0.1$ \\
\hline \multicolumn{3}{|l|}{ Monetary policy } \\
\hline Interest rate smoothing & $\rho_{R}$ & 0.9 \\
\hline Stance on inflation & $\Phi_{\pi}$ & 1.5 \\
\hline Stance on output gap & $\Phi_{y}$ & 0.5 \\
\hline \multicolumn{3}{|l|}{ Trade in international bonds } \\
\hline Risk premium parameter & $\psi_{2}=\psi_{2}^{*}$ & 0.01 \\
\hline
\end{tabular}

Source: Stähler and Thomas (2012) 
